\title{
A progressziómentes túlélést befolyásoló tényezők vizsgálata ibrutinibbel kezelt krónikus lymphoid leukémiás betegekben
}

\author{
Szerafin Lászlón ${ }^{1 @}$, Takács Péter ${ }^{2}$, Varjasi Gabriella ${ }^{1}$, Rejtő László' ${ }^{1}$, Ilonczai Péter ${ }^{1,3}$, \\ Varju Lóránt ${ }^{1}$, Keresztes Katalin ${ }^{1}$, Jakó János ${ }^{1}$ \\ 'Szabolcs-Szatmár-Bereg Megyei Jósa András Oktatókórház, Hematológiai Osztály, Nyíregyháza \\ ${ }^{2}$ Debreceni Egyetem Egészségügyi Kar, Egészségtudományi Intézet, \\ Egészségügyi Informatikai Tanszék, Nyíregyháza \\ ${ }^{3}$ Jelenlegi munkahelye: Markhot Ferenc Oktatókórház, Belgyógyászati Osztály, Eger
}

\begin{abstract}
Bevezetés: A krónikus lymphoid leukémia kezelésében jelentős előrelépést eredményezett az ibrutinibterápia bevezetése. A gyógyszer első vonalbeli és többed vonalbeli kezelése is magas remissziós arányt eredményezett, bár a terápia korai bevezetése és a kedvező genetikai eltérések esetén az eredmények jobbak. A progressziómentes túlélést befolyásoló egyéb tényezőkről azonban még kevés adat áll rendelkezésre. Célkitüzés: Krónikus lymphoid leukémiás betegek ibrutinibkezelése során a teljes hematológiai remisszió elérését és a progressziómentes túlélés időtartamát befolyásoló tényezők vizsgálata. Betegek és módszer: 47 krónikus lymphoid leukémiás beteg (életkor: 39-84 év, férfi 27, nő 20, követési idő 5-58 hónap, medián 15 hónap) klinikai és laboratóriumi adatainak retrospektív elemzése. Eredmények: A teljes hematológiai remisszió elérése független volt a betegek nemétől, életkorától, a betegség stádiumától, az immunglobulin gén nehézlánc-variábilis régió státuszától, a genetikai aberrációktól, az abszolút neutrophilszámtól, az abszolút monocytaszámtól és a vörösvértestnagyság-eloszlási görbe szélességétől. A progressziómentes túlélést a komplett remisszió elérése $(p=0,00073)$ és a magasabb abszolút neutrophilszám ( $<4 \mathrm{G} / \mathrm{l} \mathrm{vs.} \geq 4 \mathrm{G} / \mathrm{l}, p=0,022)$ befolyásolta szignifikánsan, a vörösvértestnagyság-eloszlási görbe szélességértékével való összefüggés pedig statisztikailag határértéken volt $(p=0,065)$. A Cox-féle regressziós elemzésbe bevont változók közül csak a teljes hematológiai remisszió elérése mutatott szignifikáns hatást a progressziómentes túlélésre $(p=0,0147)$. Következtetések: A teljes hematológiai remisszió elérése az egyéb vizsgált tényezőktől független, szignifikáns hatással bír a betegek progressziómentes túlélésére. Az abszolút neutrophilszám és a vörösvértestnagyság-eloszlási görbe szélessége szintén hasznos kiegészítő prognosztikus marker lehet. Az elemzett esetek száma még alacsony a komolyabb következtetések levonására, azonban így is elmondható, hogy az eredmények egy része már a szakirodalom korábbi eredményeit tükrözi.
\end{abstract}

Kulcsszavak: krónikus lymphoid leukémia, ibrutinib, teljes remisszió

\section{Investigation of factors influencing progression-free survival in patients with chronic lymphoid leukemia treated with ibrutinib}

Introduction: The introduction of ibrutinib therapy has led to significant advances in the treatment of chronic lymphocytic leukemia. Both first-line and multiple-lines treatments of the drug resulted in high remission rates, although results were better with early initiation of therapy and favorable genetic abnormalities. However, little data are available on other factors influencing progression-free survival. Objective: To investigate factors influencing the achievement of complete hematological remission and progression-free survival with ibrutinib treatment in patients with chronic lymphocytic leukemia. Patients and metods: Retrospective analysis of clinical and laboratory data from 47 chronic lymphoid leukemia patients (age: 39-84 years, male 27, female 20, follow-up 5-58 months, median 15 months). Results: Achieving complete hematologic remission was independent of patient gender, age, disease stage, immunoglobulin heavy chain variable region status, genetic aberrations, absolute neutrophil count, absolute monocyte count, and red blood cell distribution width. Progression-free survival was significantly affected by complete remission ( $p=0.00073$ ), and higher absolute neutrophil counts $(<4 \mathrm{G} / 1 \mathrm{vs} . \geq 4 \mathrm{G} / \mathrm{l}, p=0.022)$, the red blood cell distri-

@ Levelezési cím: Dr. Szerafin László, Szabolcs-Szatmár-Bereg Megyei Jósa András Oktatókórház, Hematológiai Osztály, 4400 Nyíregyháza, Szent István u. 68.; E-mail: dr.szerafin.laszlo@szszbmk.hu 
bution width was statistically less significant $(p=0.065)$. Of the variables included in the Cox regression analysis, only the achievement of complete hematologic remission had a significant effect on progression-free survival $(p=0.0147)$. Conclusions: Achieving complete hematologic remission, independent of the other factors studied, has a significant effect on patients' progression-free survival. Absolute neutrophil count and red blood cell distribution width can also be a useful additional prognostic marker. The number of analyzed cases is still low to draw more serious conclusions, but it can still be said that some of the results already reflect previous results in the literature.

Keywords: chronic lymphocytic leukemia, ibrutinib, complete remission

(Beérkezett: 2020. november 24.; elfogadva: 2021. február 14.)

\section{Rövidítések}

AMC - abszolút monocytaszám; ANC - abszolút neutrophilszám; CLL - krónikus lymhoid leukémia; CR - teljes remisszió; FISH - fluorescens in situ hibridisatio; IGHV M/U - immunglobulin gén nehézlánc-variábilis régió mutált/nem mutált státusz; OS - teljes túlélés; PFS - progressziómentes túlélés; PR - részleges remisszió; PD - progresszív betegség; R/R refrakter/relabált; RDW - red blood cell distribution width (vörösvértestnagyság-eloszlási görbe szélessége [variációs koefficiens]); SD - stabil betegség

\section{Bevezetés}

A krónikus lymphoid leukémia (CLL) kezelésében jelentős előrelépést eredményezett az ibrutinib terápia bevezetése. A gyógyszer első vonalbeli és többed vonalbeli kezelése is magas remissziós arányt eredményezett, bár a terápia korai bevezetése és a kedvező genetikai eltérések, valamint mélyebb remisszió elérése esetén az eredmények jobbak [1-6]. A progressziómentes túlélést befolyásoló egyéb tényezőkről azonban még kevés adat áll rendelkezésre. Ezért jelen közleményünkben a CLL-es betegek ibrutinibkezelése során a teljes hematológiai remisszió elérését és a progressziómentes túlélés időtartamát befolyásoló tényezőket vizsgáltuk. A klasszikus prognosztikus vizsgálatokon - fluoreszcens in situ hibridizációvizsgálatok (FISH), immunglobulin gén nehézlánc-variábilis régió mutációstátusz (IGHV), stádium stb. - kívül vizsgáltuk a komplett remisszió (CR) elérésének, a diagnózis időpontjában észlelt abszolút monocytaszám (AMC), abszolút neutrophilszám (ANC) és a vörösvértestnagyság-eloszlási görbe szélessége [variációs koefficiens] (RDW) jelentőségét a progressziómentes túlélésre (PFS).

\section{Betegek és módszer}

\section{Betegek és adatgyüjtés}

47 CLL-es beteg adatait elemeztük. Férfi: 27, nő: 20, életkor 39-84 (medián 70) év, 2020. 05. 31-ig a betegek medián követési ideje 15 hónap volt (5-58 hónap). A diagnózis időpontjában a betegek Rai-féle stádium szerinti megoszlása: O.: 3, I.: 18, II.: 6, III.: 2, IV.: 18 fö. Az ibrutinibkezelés bevezetése előtt 13 betegnél volt lehetőségünk IGHV meghatározásra, közülük 12 nem mutált státuszú volt. 17p deléció 6/46, TP53-mutáció 10/26 esetben fordult elő, 12 betegnél többes genetikai aberrációt lehetett kimutatni. Az ibrutinibet 7 beteg első vonalbeli kezelésként, 16 beteg második, 18 beteg harmadik és 6 beteg negyedik vonalbeli kezelésként kapta. A teljes hematológiai remissziót (CR) Hallek és mtsai közleményében leírtak alapján határoztuk meg [7]. CR-t 19, részleges remissziót (PR) 12, stabil állapotot (SD) 14 betegnél sikerült elérni. Két beteg állapota progrediált (PD). A követési idő alatt 7 beteg hunyt el. Betegeink fontosabb adatait az 1. táblázatban mutatjuk be. Az ibrutinibkezelés elkezdésére minden esetben a klinikai progresszió miatt került sor.

1. táblázat. Betegeink fontosabb adatai

\begin{tabular}{lc}
\hline$n$ & 47 \\
\hline Nem & Férfi: 27, Nő: 20 \\
Életkor & 39-84 év, medián: 70 év \\
Követési idő & $5-58$ hó, medián 15 hó \\
Rai-stádium: 0. & $3 / 47$ \\
I. & $18 / 47$ \\
II. & $6 / 47$ \\
III. & $2 / 47$ \\
IV. & $18 / 47$ \\
IGHV-mutált/nem mutált & $1 / 13 / 12 / 13$ \\
\hline
\end{tabular}


1. táblázat. (folyt.)

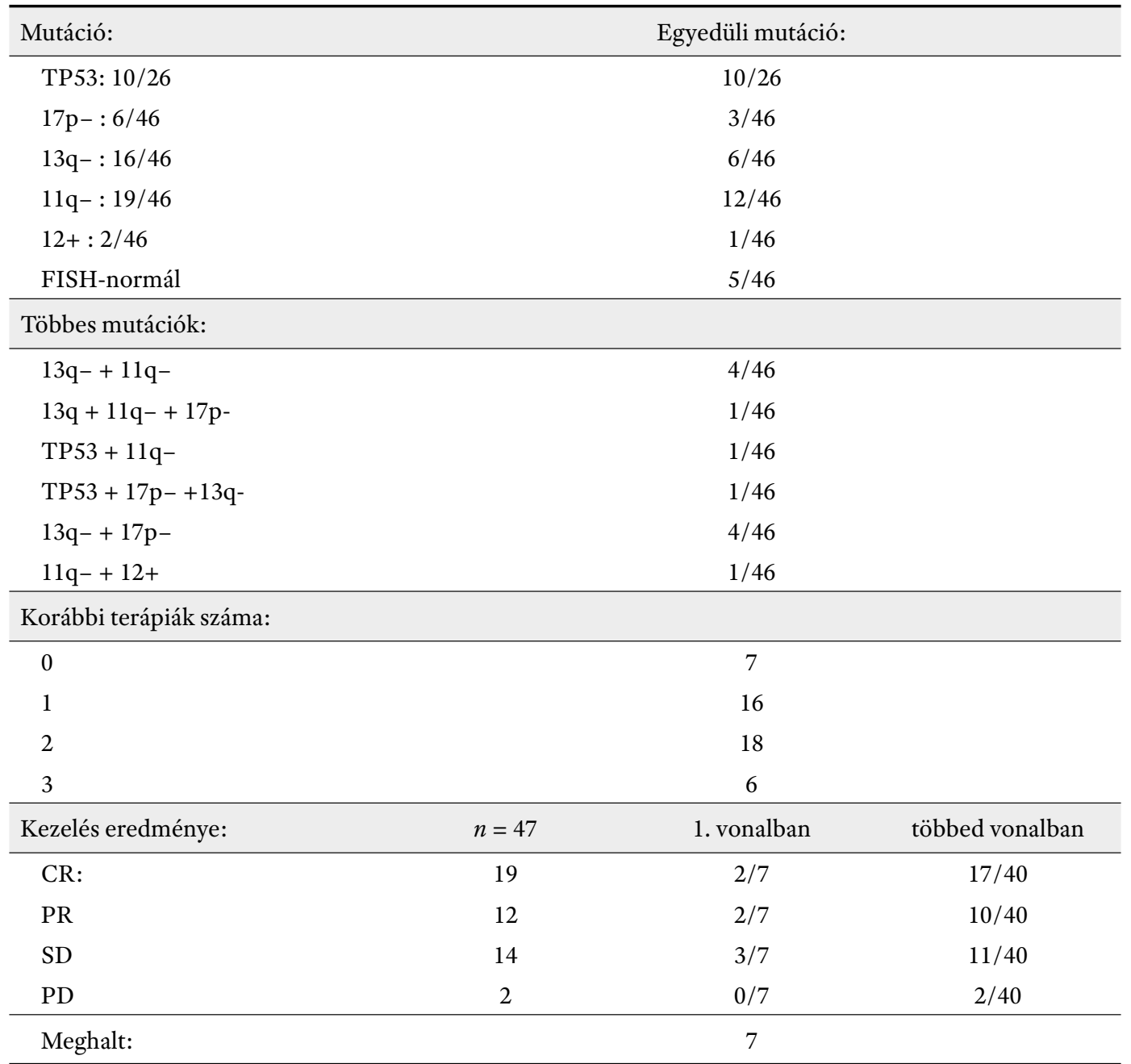

IGHV M/U - immunglobulin gén nehézlánc-variábilis régió mutált/nem mutált státusz; FISH - fluorescens in situ hibridisatio; CR - teljes remisszió; PR - részleges remisszió; PD - progresszív betegség; SD - stabil betegség

\section{Statisztikai módszerek}

A teljes hematológiai remisszió elérését befolyásoló tényezők szignifikáns voltát Khí-négyzet próbával, a PFS-t Kaplan-Meyer túlélési görbékkel, azok szignifikáns voltát log-rank-teszttel ellenőriztük. A Cox-féle regressziós elemzésbe az életkor, nem, fehérvérsejtszám, abszolút neutrophilszám (ANC), abszolút monocytaszám (AMC), a CR elérése vagy hiánya, valamint Rai-féle stádium sze- rinti változók lettek bevonva. A $p<0,05$ értékeket tekintettük szignifikánsnak.

\section{Eredmények}

A vizsgált CLL-es betegeknél a CR elérése függetlennek bizonyult a nemtől, életkortól, Rai-féle stádiumtól, IGHV-státusztól, a genetikai eltérésektől, az ANC-, AMC- és RDW-értékektől (2. táblázat). A vizsgált té-

2. táblázat. A krónikus lymphoid leukémia ibrutinibkezelése során a teljes remisszió elérését befolyásoló tényezők

\begin{tabular}{llcccc}
\hline & & CR $(n=19)$ & No CR $(n=28)$ & $\chi^{2}$ & $p$ \\
& & $n$ & $n$ & & \\
\multirow{2}{*}{ Nem } & Férfi & 10 & 17 & 0,0628 & 0,$8030 ;$ n.sz. \\
& Nő & 9 & 11 & & \\
\multirow{2}{*}{ Életkor } & $\leq 65$ év & 7 & 12 & 0,018 & 0,$9128 ;$ n.sz. \\
& $>65$ év & 12 & 16 & 0, \\
\hline
\end{tabular}


2. táblázat. (folyt.)

\begin{tabular}{|c|c|c|c|c|c|}
\hline & & $\begin{array}{c}\mathrm{CR}(n=19) \\
n\end{array}$ & $\begin{array}{c}\text { No CR }(n=28) \\
n\end{array}$ & $\chi^{2}$ & $p$ \\
\hline \multirow{2}{*}{ Stádium } & Rai $0-$ II. & 12 & 16 & \multirow{2}{*}{0,225} & \multirow{2}{*}{0,$6349 ;$ n.sz. } \\
\hline & Rai III-IV. & 6 & 13 & & \\
\hline \multirow{2}{*}{$\mathrm{IgHV}$} & M & 0 & 1 & \multirow{2}{*}{0,00645} & \multirow{2}{*}{ 0,9360; n.sz. } \\
\hline & $\mathrm{UM}$ & 6 & 6 & & \\
\hline \multirow{2}{*}{ FISH } & $17 \mathrm{p}-/ \mathrm{TP} 53 / 11 \mathrm{q}-$ & 12 & 19 & \multirow{2}{*}{0,0378} & \multirow{2}{*}{0,$8459 ;$ n.sz. } \\
\hline & normális / 13q- & 7 & 8 & & \\
\hline \multirow{2}{*}{ AMC } & $0,25-0,75 \mathrm{G} / \mathrm{L}$ & 12 & 15 & \multirow{2}{*}{0,124} & \multirow{2}{*}{0,$7250 ;$ n.sz. } \\
\hline & $<0,25$ vagy $>0,75 \mathrm{G} / \mathrm{L}$ & 7 & 13 & & \\
\hline \multirow{2}{*}{ ANC } & $>4 \mathrm{G} / 1$ & 11 & 12 & \multirow{2}{*}{0,511} & \multirow{2}{*}{ 0,4747; n.sz. } \\
\hline & $\leq 4 \mathrm{G} / \mathrm{L}$ & 8 & 16 & & \\
\hline \multirow{2}{*}{ RDW } & $\leq 16 \%$ & 14 & 19 & \multirow{2}{*}{0,0168} & \multirow{2}{*}{ 0,9174; n.sz. } \\
\hline & $>16 \%$ & 5 & 9 & & \\
\hline
\end{tabular}

IGHV M/U - immunglobulin gén nehézlánc-variábilis régió mutált/nem mutált státusz; FISH - fluorescens in situ hibridisatio; AMC - abszolút monocytaszám; ANC - abszolút neutrophilszám; RDW- red blood cell distribution width

nyezők közül a PFS-t a CR elérése, valamint az ANCértéke befolyásolta szignifikánsan, az RDW hatása a szignifikancia határán volt (3. táblázat). A PFS idejét leghatározottabban a CR elérése befolyásolta $(p=0,00073)$ (1. ábra). Ezenkívül a PFS szintén szignifikánsan kedvezőbb volt $\geq 4 \mathrm{G} / 1 \mathrm{ANC}$ esetén (2. ábra). Ha a betegek $\mathrm{RDW}$-értéke $<16 \%$, normális volt, a túlélési görbe szintén kedvezőbb és a szignifikanciahatáron volt $(p=0,065)$ (3. ábra). A Cox-féle regressziós elemzésbe a nem, életkor, fehérvérsejtszám, ANC, AMC, CR, Rai-féle stá- diumváltozókat vontuk be (a statisztikai elemzéshez ezen adatok voltak megfelelő mennyiségben elérhetőek). A bevont változók közül csupán a CR mutatott szignifikáns hatást a PFS-re $(p=0,0147)$. Az ibrutinibet első vonalbeli kezelésként kapó betegek között nem észleltünk progressziót a megfigyelési idő alatt. A két progressziót mutató beteg az ibrutinibet második vagy többedik vonalbeli kezelésként kapta (1. táblázat). (A két csoport között további statisztikai elemzésre - az első vonalban kezeltek kis száma miatt - nem nyílt lehetőség.)

3. táblázat. A progressziómentes túlélésre ható vizsgált tényezők krónikus lymphoid leukémiában ibrutinibkezelés során

\begin{tabular}{lc}
\hline & $p$ \\
\hline ANC < 4 G/l vs. ANC $\geq 4$ G/l & 0,022 sz. \\
Stádium Rai: 0-I-II. vs. Stádium Rai: III-IV. & 0,75 n.sz. \\
AMC 0,25-0,75 G/l vs. AMC < 0,25 vagy > 0,75 G/1 & 0,14 n.sz. \\
CR vs. PR & 0,00073 sz. \\
CR vs. PR/SD/PD & 0,0001 sz. \\
IgHV-M vs. IgHV-UM & 0,86 n.sz. \\
Életkor: $\leq 65$ év vs. > 65 év & 0,46 n.sz. \\
Nem: férfi vs. nő & 0,75 n.sz. \\
RDW $\leq 16 \%$ vs. > 16\% & 0,065 határérték \\
Genetika: TP53/17p del vs. 13q, 11+, 12+, norm. & 0,66 n.sz. \\
\hline
\end{tabular}

ANC - abszolút neutrophilszám; AMC - abszolút monocytaszám; CR - teljes remiszszió; PR - részleges remisszió; PD - progresszív betegség; SD- stabil betegség; IGHV M/U - immunglobulin gén nehézlánc-variábilis régió mutált/nem mutált státusz; RDW - red blood cell distribution width; FISH - fluorescens in situ hibridisatio 


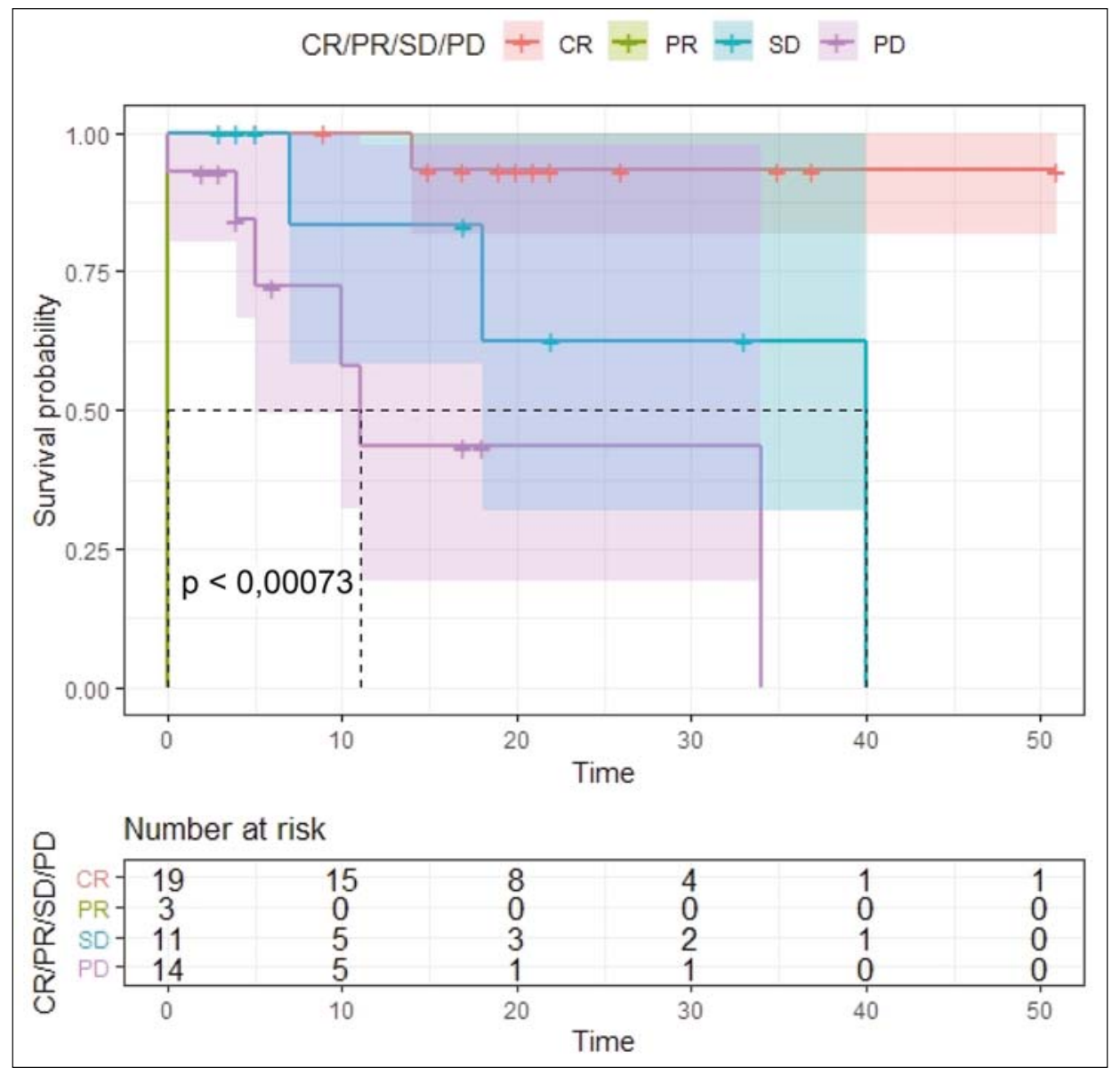

1. ábra. Ibrutinibbel kezelt krónikus lymphoid leukémiás betegek progressziómentes túlélése az elért remisszió mélységének függvényében

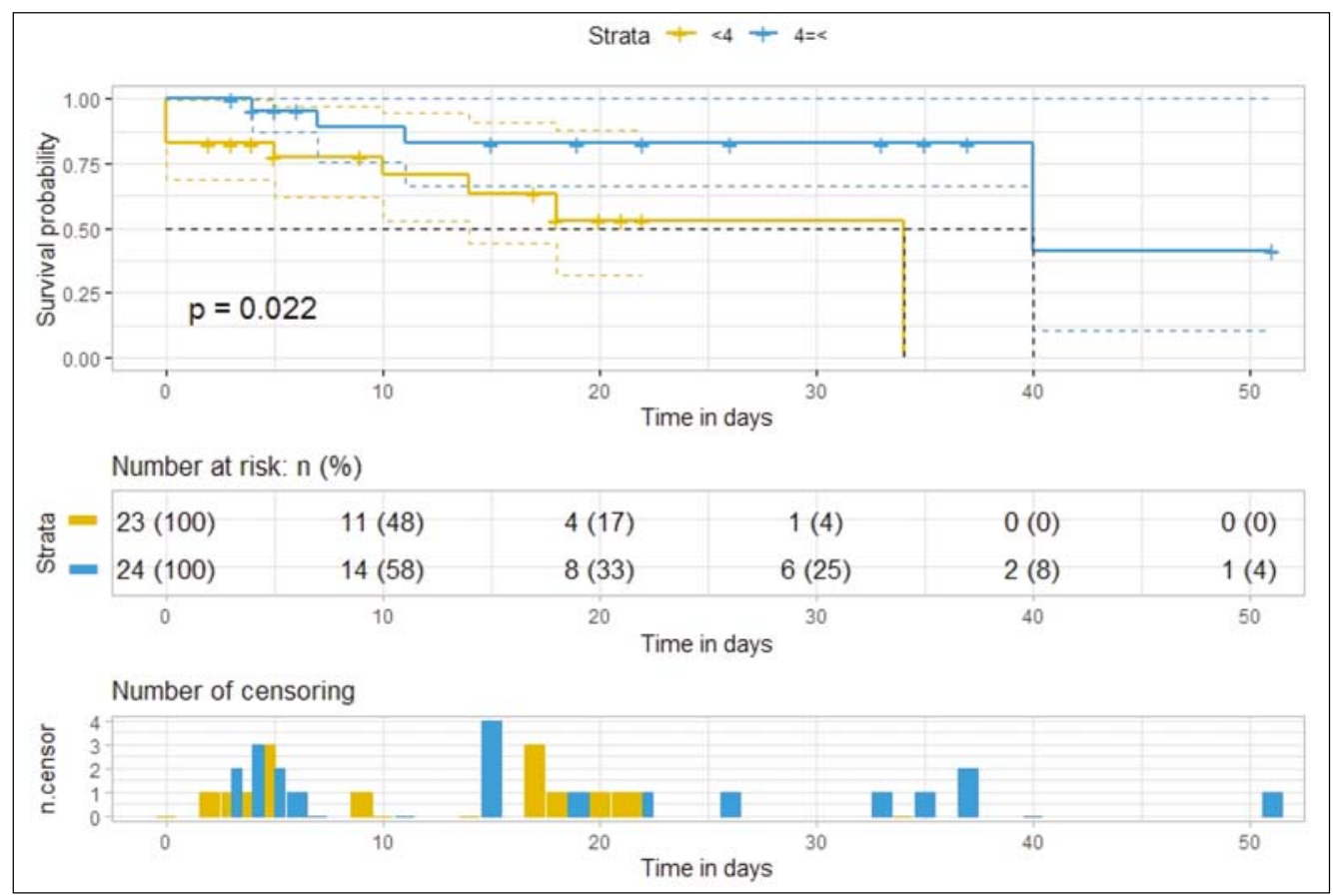

2. ábra. Ibrutinibbel kezelt krónikus lymphoid leukémiás betegek progressziómentes túlélése az abszolút neutrophilszám függvényében 


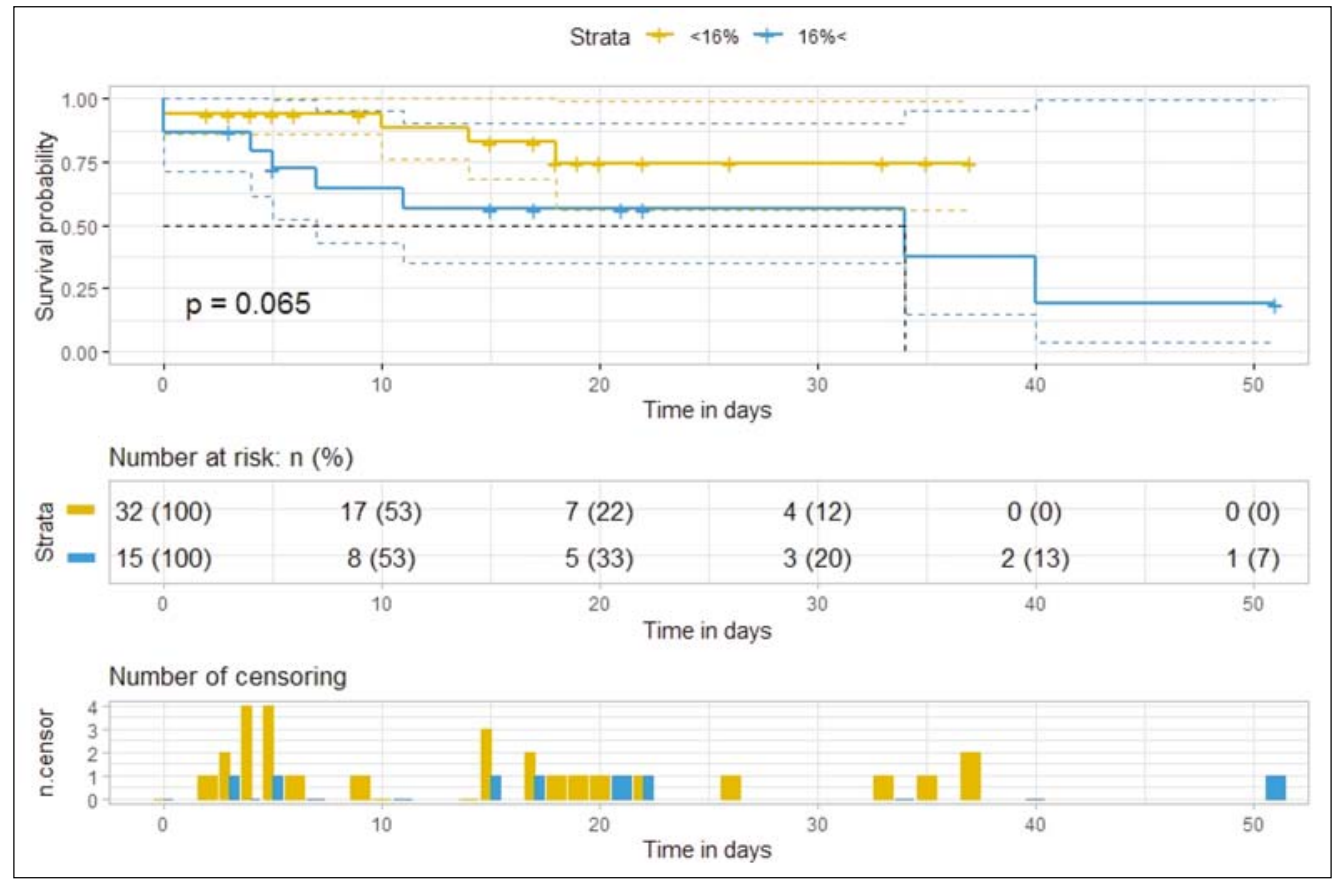

3. ábra. Ibrutinibbel kezelt krónikus lymphoid leukémiás betegek progressziómentes túlélése az RDW függvényében

\section{Megbeszélés}

Az ibrutinibterápia bevezetése a CLL kezelésében jelentős előrelépést eredményezett. A korábbi kezelésekkel összehasonlítva jelentősen megnőtt a remissziók aránya és a PFS ideje [1-6]. Az ibrutinib monoterápiában részesülő betegek 5 éves PFS-e korábban nem kezelt betegek esetében $92 \%$ PFS-t, R/R betegeknél $44 \%$ PFS-t eredményezett. A rossz prognózist jelentő genetikai elváltozásokkal bíró betegeknél is a korábbiakhoz képest számottevő eredményt lehetett elérni: PFS: del(11q) 51 hó, del(17p) - 26 hó, IGHV-U - 43 hó [1, 2]. Ibrutinibbel az esetek egy kisebb részében - perifériás vérben és csontvelőben mérve is - reziduális betegségmentességet is el lehetett érni [6]. Az ibrutinib alkalmazása a korábbi terápiáknál egyértelműen hatékonyabbnak bizonyult [3]. A mélyebb remisszió javította a PFS-t [5]. A korábban nem kezelt és nem nagy tumortömeggel bíró betegek PFS-e szintén kedvezőbb volt [4]. A reziduális betegségmentességet azonban csak a betegek viszonylag kis részénél lehet elérni, és az általunk követett betegek száma is viszonylag alacsony volt, emiatt a remisszió megítélésére Hallek és mtsai által közzétett konszenzus [7] kritériumait alkalmaztuk, amely a hematológiai remisszió mértékét jelzi. Eredményeink alapján a CR elérését nem befolyásolta a betegek életkora, neme, a betegség stádiuma, az IGHV-státusz, a FISH-vizsgálattal észlelt eltérések, sem az AMC-, ANC- és RDW-értékek. Strati és mtsai az általuk vizsgált CLL-es betegeknél szintén nem találtak összefüggést az életkorral, nemmel, stádiummal, nyirokcsomótömeggel, korábbi kezelésekkel és a genetikai eltérésekkel [8]. A PFS időtartamát a CR-be jutott betegeknél találtuk a leghosszabbnak (1. ábra), ez megegyezik a Strati és mtsai által észleltekkel [8]. Az egyéb vizsgált prognosztikus markerek közül az IGHV-mutáció-státusz és a FISH-vizsgálattal észlelt eltérések nem mutattak szignifikáns hatást a PFS-re. Strati és mtsai hasonló témájú közleményében a $17 \mathrm{p} / \mathrm{TP} 53$-mutáció és a komplex kariotípus eltérések hiánya, valamint a $\mathrm{CR}$ elérése mutatott összefüggést a hosszabb PFS-sel [8]. A tumorok biológiai viselkedését nagymértékben befolyásolja azok mikrokörnyezete, ez a CLL-re is igaz. CLL-ben az AMC-t a túlélés független rizikófaktorának találták, $<0,91 \mathrm{G} / 1$ AMC rövidebb OS-sel és terápiamentes túléléssel társult. A diagnóziskor észlelt monocytosis összefüggést mutatott a lymphocytaszámmal, a $17 \mathrm{p}$ és $11 \mathrm{q}$ delécióval, az IGHV mutáció státusszal és a betegség stádiumával [9]. Herishanu és mtsai nagyobb AMC értékú betegeikben magasabb ALC értéket és rövidebb terápiamentes időtartamot találtak, ugyanakkor a normálisnál alacsonyabb AMC esetén gyakoribb volt a fertőzések okozta halálozás [10]. Hasonló tárgyú korábbi közleményünkben mi is ugyanerre a következtetésre jutottunk [11]. Friedman és mtsai szintén megerősítették, hogy a diagnóziskor emelkedett AMC-érték a CLL-es betegek kedvezőtlenebb kórjóslatával és gyorsabb betegség progresszióval jár együtt [12]. Hasonló eredményeket írtak le diffúz nagy B-sejtes lymphomás betegekben is [13-15]. Ezen észlelések hátterében a CLL-es mikrokörnyezet részét is képező tumor-asszociált makrofágoknak van szerepük, amelyek terápiás célpontként is szolgálhatnak [16-18]. Strati és mtsai a tumor-asszociált makrofágokra jellemző CD163-pozitív sejtek arányának megnövekedését tapasztalták rövidebb PFS-ű CLL-es betegeikben [8]. 
Ugyanakkor az ibrutinib módosítja a monocyta/makrofág populáció működését CLL-ben [19]. Bár a CR kialakulása és a PFS vonatkozásában mi nem találtunk szignifikáns összefüggést az AMC-vel, de ennek - az irodalmi adatok tükrében - további vizsgálata célszerű nagyobb betegszámmal és hosszabb időtartamban. CLL-es betegeink között $\geq 4$ G/1 ANC-értékü betegek progressziómentes túlélése kedvezőbbnek bizonyult a $<4$ G/l értéküekéhez képest. Ennek hátterében a kisebb tumortömeg és a jobb minőségű immunmüködés állhat. Levi és mtsai a magasabb (>7 G/1) ANC-vel és normál AMC-vel rendelkező betegek prognózisát szintén kedvezőbbnek, halálozási arányukat alacsonyabbnak, a kezelésig eltelt időt hosszabbnak találták, mint a neutrophilia nélküli vagy monocytosisos betegeik esetében [20]. Az RDW emelkedését a vörösvértest anyagcsere mérsékelt csökkenésének tulajdonítják, amely számos kóros állapotban a homeosztázis adaptációját jelzi [21, 22]. A magasabb RDW - főleg 65 évesnél idősebbekben - az élettartam megrövidülését jelezheti vérszegénység nélkül is [23-25]. Szintén magasabb RDW-értékeket találtak krónikus vesebetegekben, ami az endothel diszfunkciót tükrözte [26]. A RDW-szintet ugyancsak prognosztikus jelnek találták különböző gasztrointesztinális betegségekben [25]. Bronchus carcinoma esetén az emelkedett RDW összefüggését találták a stádiummal és a rosszabb prognózissal [27]. Hematológiai betegségek közül az emelkedett RDW csökkent PFS-sel társult myeloma multiplexben [28]. A normálisnál magasabb RDW-szint ugyancsak kedvezőtlen prediktív prognosztikus tényezőnek bizonyult diffúz nagy B-sejtes lymphomás betegekben [29], valamint nagy rizikójú myelodysplasiás szindrómában [30-31] és CLLben is [32]. CLL-es betegekben az emelkedett RDW-szint előrehaladottabb betegséggel, megrövidült túléléssel és rövidebb kezelésmentes időtartammal társult [32]. Saját betegeink között a PFS szignifikancia határon lévő csökkenését tapasztaltuk emelkedett RDW-szint esetén. Ibrutinibkezeléssel kapcsolatban Gordon és mtsai a 70 év feletti életkort, a refrakter/relabált $(R / R)$ betegséget és a $>6$ CIRS komorbiditási indexből képzett magasabb pontszámot prognosztikus indexként ajánlották az ibrutinibbel kezelt CLL-es betegek eseménymentes és teljes túlélésének előrejelzésére [33]. Egyéb irodalmi adatokkal összhangban a CR elérése az egyéb vizsgált tényezőktől független, szignifikáns hatással bír a betegek progressziómentes túlélésére. Az ANC és az RDW szintén hasznos kiegészítő prognosztikus marker lehet a betegek kórjóslatának meghatározásában az általánosan használt prognosztikus tényezők mellett, amelyekre szintén fel kívántuk hívni a figyelmet. Az elemzett esetek száma még alacsony, a vizsgált betegcsoport heterogén és a követési idő rövid a komolyabb következtetések levonására, ezért a statisztikai adatok értelmezése, értékelése is óvatosságot igényel, azonban így is elmondható, hogy az eredményeink egy része a szakirodalom korábbi eredményeit tükrözi. Megerősítésükhöz további vizsgálatok szükségesek.
Nyilatkozat: A közlemény más folyóiratban nem jelent meg, máshova beküldésre nem került. A levelező szerző elolvasta a szerzői útmutatót.

Érdekeltségek: A szerzőknek nincsenek érdekeltségeik.

Anyagi támogatás: A közlemény megírása anyagi támogatásban nem részesült.

Szerzői munkamegosztás: Sz.L.: témafelvetés, irodalomkutatás, az adatok feldolgozása, a közlemény megírása. T.P.: a statisztikai számítások elvégzése. V.G.: az adatok feldolgozása. R.L., I.P., V.L., K.K.: a betegek kezelése. J.J.: a közlemény megírása

\section{Irodalom}

[1] O'Brien S, Jones JA, Coutre SE, et al. Ibrutinib for patients with relapsed or refractory chronic lymphocytic leukaemia with $17 \mathrm{p}$ deletion (RESONATE-17): a phase 2, open-label, multicentre study. Lancet Oncol 2016; 17: 1409-1418.

[2] O’Brien S, Furman RR, Coutre S, et al. Single-agent ibrutinib in treatment-naïve and relapsed/refractory chronic lymphocytic leukemia: a 5-year experience. Blood 2018; 131: 1910-1919.

[3] Woyach JA, Ruppert AS, Heerema NA, et al. Ibrutinib regimens versus chemoimmunotherapy in older patients with untreated CLL. N Engl J Med 2018; 379: 2517-2528.

[4] O'Brien SM, Jaglowski S, Byrd JC, et al. Prognostic factors for complete response to ibrutinib patients with chronic lymphocytic leukemia: A pooled analysis of 2 clinical trials. JAMA Oncol 2018; 4: $712-716$.

[5] Sigmund A, Huang Y, Ruppert AS, et al. Depth of response and progression free survival in CLL patients on ibrutinib [abstract]. J Clin Oncol 2018; 36(Suppl 15). Abstract 7514.

[6] Byrd JC, Hillmen P, O'Brien S, et al. Long-term follow-up of the RESONATE phase 3 trial ibrutinib vs. ofatumumab. Blood 2019; 133: 2031-2042.

[7] Hallek M, Cheson BD, Catovsky D, et al. International workshop on chronic lymphocytic leukemia. Guidlines for the diagnosis and treatment of chronic lymphocytic leukemia: a report from the International workshop on chronic lymphocytic leukemia updating the National Cancer Institute - Working Group 1996 Guidelines. Blood 2008; 111: 5446-5456.

[8] Strati P, Schlette EJ, Solis Soto LM, et al. Achieving complete remission in CLL patients treated with ibrutinib: clinical significance and predictive factors. Blood 2020; 135: 510-513.

[9] Mazumdar R, Evans P, Culpin R, et al. The automated monocyte count is independently predictive of overall survival from diagnosis in chronic lymphocytic leukaemia and of survival following first-line chemotherapy. Leuk Res 2013; 6: 614-618.

[10] Herishanu J, Kay S, Sarid N, et al. Absolute monocyte count trichotomizes chronic lymphocytic leukemia into high risk patients with immune dysregulation, disease progression and poor survival. Leuk Res 2013; 37: 1222-1228.

[11] Szerafin L, Jakó J, Riskó F. Prognostic value of absolute monocyte count in chronic lymphocytic leukaemia. [Az abszolút monocytaszám prognosztikus értéke krónikus lymphoid leukaemiában.] Orv Hetil 2015; 156: 592-597. [Hungarian]

[12] Friedman DR, Sibley AB, Owzar K, et al. Relationship of blood monocytes with chronic lymphocytic leukemia aggressiveness and outcomes: a multi-institutional study. Am J Hematol 2016; 91: 687-691.

[13] Kridel R, Steidl C, Gascoyne RD. Tumor-associated macrophages in diffuse large B-cell lymphoma. Haematologica 2015; 100: 143145 . 
[14] Riihijarvl S, Fiskvik I, Taskinen M, et al. Prognostic influence of macrophages in patients with diffuse large B-cell lymphoma: a correlative study from a Nordic phase II trial. Haematologica 2015; 100: 238-245.

[15] Marcheselli R, Franchesetto A, Sacchi S, et al. The prognostic role of end of treatment FDG-PET-CT in patients with diffuse large B cell lymphoma can be improved by considering it with absolute monocyte count at diagnosis. Leuk Lymphoma 2019; 60: 19581964.

[16] Burger JA, Gribben JG. The microenvironment in chronic lymphocytic leukemia (CLL) and other B cell malignancies: insight into disease biology and new targeted therapies. Semin Cancer Biol 2014; 24: 71-81.

[17] Mantovani A, Marchesi F, Malesci A, et al. Tumour-associated macrophages as treatment targets in oncology. Nat Rev Clin Oncol 2017; 147: 399-416.

[18] Asmaa MZ, Sawsan MM, Ahmad FT, et al. Monocytic myeloid-derived suppressor cells in chronic lymphocytic leukemia patients: A single center experience. Leuk Lymphoma 2020; 61: 1645-1652.

[19] Fiorcari S, Maffei R, Auditro V, et al. Ibrutinib modifies the function of monocyte/macrophage population in chronic lymphocytic leukemia. Oncotarget 2016; 7: 65968-65981.

[20] Levy I, Vadasz Z, Polliack A, et al. The frequency and prognostic value of neutrophilia in chronic lymphocytic leukemia. Anticancer Res 2018; 38: 4731-4734.

[21] Patel KV, Ferrucci L, Ershler WB, et al. Red blood cell distribution width and the risk of death in middle-aged and older adults. Arch Intern Med 2009; 169: 515-523.

[22] Patel HH, Patel HR, Higgins JM. Modulation of red blood cell population dynamics is a fundamental homeostatic response to disease. Am J Hematol 2015; 90: 422-428.

[23] Lam AP, Gundabolu K, Sridharan A, et al. Multiplicative interaction between mean corpuscular volume and red cell distribution width in predicting mortality of elderly patiens with and without anemia. Am J Hematol 2013; 88: e245-e248.
[24] Horne BD, Anderson JL, Muhlestein JB, et al. Complete blood risk score its components, including RDW, are associated with mortality in the JUPITER trial. Eur J Prev Cardiol 2014; 22: 519526.

[25] Goyal H, Lippi G, Gjymishka A, et al. Prognostic significance of red blood cell distribution width in gastrointestinal disorders. World J Gastroenterol 2017; 23: 4879-4891.

[26] Solak Y, Yilmaz MI, Saglam M, et al. Red cell distribution width is independently related to endothelial dysfunction in patients with chronic kidney disease. Am J Med Sci 2014; 347: 118-124.

[27] Koma Y, Onishi A, Matsuoka H, et al. Increased red blood cell distribution width associates with cancer stage and prognosis in patients with lung cancer. Plos One 2013; 8: e80240.

[28] Lee H, Kong S-Y, Sohn Y-J, et al. Elevated red blood cell distribution width as a simple prognostic factor in patients with symptomatic multiple myeloma. BioMed Res Int 2014; 2014: 145619.

[29] Beltran BE, Paredes S, Castro D, et al. High red cell distribution width is an adverse predictive and prognostic factor in patients with diffuse large B-Cell lymphoma treated with chemoimmunotherapy. Clin Lymphoma Myeloma Leuk 2019; 19: e551-e557.

[30] Baba Y, Saito B, Shimada S, et al. Association of red cell distribution width with clinical outcomes in myelodysplastic syndrome. Leuk Res 2018; 67: 56-59.

[31] Shi Z, Li B, Huang H, et al. Prognostic impact of red blood cell distribution width in myelodysplastic syndromes. Br J Haematol 2019; 186: 327-384.

[32] Podhorecka M, Halicka D, Szymczyk A, et al. Assessment of red blood cell distribution with as a prognostic marker in chronic lymphocytic leukemia. Oncotarget 2016; 7: 32846-32853.

[33] Gordon MJ, Sitlinger A, Salous T, et al. A simplified prognostic index for chronic lymphocytic leukemia treated with ibrutinib: Results from a multicenter retrospective cohort study. Leuk Res 2020; 89: 106-302.

A cikk a Creative Commons Attribution 4.0 International License (https://creativecommons.org/licenses/by/4.0/) feltételei szerint publikált Open Access közlemény, melynek szellemében a cikk bármilyen médiumban szabadon felhasználható, megosztható és újraközölhető, feltéve, hogy az eredeti szerző és a közlés helye, illetve a CC License linkje és az esetlegesen végrehajtott módosítások feltüntetésre kerülnek. (SID_1) 